\title{
Association of TLR3 single nucleotide polymorphisms with susceptibility to HTLV-1 infection in Iranian asymptomatic blood donors
}

\author{
Hossein Mehrabi Habibabadi ${ }^{11]}$, Masoud Parsania ${ }^{[2]}$, \\ Ali Akbar Pourfathollah ${ }^{[3]}$, Setareh Haghighat ${ }^{[1]}$ and Zohreh Sharifi ${ }^{[4]}$
}

\begin{abstract}
[1]. Department of Microbiology, Faculty of Advanced Science and Technology, Tehran Medical sciences, Islamic Azad University, Tehran, Iran.
[2]. Department of Microbiology, Faculty of Medicine, Tehran Medical sciences, Islamic Azad University, Tehran, Iran.

[3]. Department of Immunology, Faculty of Medical Sciences, Tarbiat Modares University, Tehran, Iran.

[4]. Blood Transfusion Research Center, High Institute for Research and Education in Transfusion Medicine, Tehran, Iran
\end{abstract}

\begin{abstract}
Introduction: The human T-lymphotropic virus type 1 (HTLV-1) has a single-stranded RNA genome and expresses specific proteins that have oncogenic potential. Approximately 15 to 20 million people worldwide have been infected by this virus. Changes in protein or gene expression are the effects of single nucleotide polymorphisms (SNPs) within the Toll-like receptor 3 (TLR3) gene. The function and efficacy of signal transduction also lead to modified immune responses. The present study aimed to investigate the association of SNPs within TLR3 (rs3775291 and rs3775296) with susceptibility to HTLV-1 infection in Iranian asymptomatic blood donors. Methods: This study was performed on 100 HTLV-1-infected asymptomatic blood donors and 118 healthy blood donors. Genomic DNA from all participants was purified and then amplified using specific PCR primers. SNPs within TLR3 were evaluated using the restriction fragmentation length polymorphism technique, and the results were analyzed using SPSS software (version 22). Results: The frequencies of the TLR3 (rs3775296) CC, CA, AA genotypes were 70\%, 24\%, and $6 \%$ in the patient group, and 50.8\%, 44.9\%, and $4.2 \%$ in the control group, respectively. There was a significant difference in the frequency distribution of TLR3 (rs3775296) genotypes and alleles, but not in the frequency distribution of TLR3 (rs3775291) genotypes between the patient and control groups. Conclusions: The TLR3 SNP rs3775296 was significantly associated with HTLV-1 infection and may be a protective factor against this viral infection.
\end{abstract}

Keywords: HTLV-1. SNP. TLR3. Restriction fragment length polymorphism.

\section{INTRODUCTION}

Infection with human T-lymphotropic virus type 1 (HTLV-1) may cause disease. It is currently estimated that 15 to 20 million people worldwide are infected with this virus ${ }^{1,2}$. HTLV-1 infection is endemic in some parts of the world, including southern Japan, some Caribbean countries, sub-Saharan Africa, South America, Papua New Guinea, the islands of Melanesia and Solomon in Oceania, and northeastern Iran (Khorasan Province) $)^{2,3,4}$.

The immune system plays a decisive role in determining the fate of infection by infectious agents. - (TLRs) are usually expressed on the cell surface and play significant roles in innate immune

\footnotetext{
Corresponding author: Dr. Zohreh Sharifi.

e-mail: z.sharifi@ibto.ir / z.sharifi@tmi.ac.ir

(D) https://orcid.org/0000-0002-6600-910X

Received 3 February 2020

Accepted 3 April 2020
}

responses; 11 human TLR family members have been discovered. TLR3 is found in endosomal compartments where it recognizes retroviral double-stranded RNA and induces antiviral activities by producing inflammatory cytokines and type I interferons (IFNs).

Gene polymorphisms, SNPs, are common, appearing about $1 \%$ of the general population. They can lead to amino acid substitutions and altered gene promoter activity ${ }^{5-8}$, affecting gene expression, mRNA conformation and stability, or protein structure and function ${ }^{9}$. It has been suggested that polymorphisms in the TLR3 promoter region may affect gene expression and cause transcriptional modulation of $T L R 3^{10}$. TLR3, after binding to ligands, induces inflammatory cytokine production, triggering induction of type I IFNs through nuclear factor- $\mathrm{kB}$, or interferon regulatory factor (IRF)-dependent signaling pathways. Amino acid substitution may be the result of the rs3775291 SNP. Mutations at this position may cause mRNA configuration changes and impair the function of TLR3 protein due to stringent purifying selection pressure related to the $\mathrm{C}$ allele. SNP 
rs3775296 is in the 5'-untranslated region (UTR) of TLR3. It has been suggested that several polymorphisms that alter amino acid residues in TLR3 can lead to altered protein structure and function. Therefore, they may cause downregulation of the expression of TLR3 and reduce functional activity needed for appropriate signaling ${ }^{11}$.

Several SNPs located on TLR3 (rs3775290, rs1879026, rs3775296, rs3775291, rs5743305 and rs13126816) have been selected as the targets of studies to assess the risk of viral infection and related diseases ${ }^{12-16}$. Since no studies have been performed on the possible association of TLR 3 polymorphisms with susceptibility to HTLV-1 infection, we aimed to investigate TLR 3 polymorphisms involving rs3775291 and rs3775296 in HTLV-1-infected individuals, in comparison to healthy individuals.

\section{METHODS}

\section{Patients and samples}

This case control study selected 100 blood samples from blood donors in Khorasan Razavi Province (which is an endemic area of HTLV-1 in Iran) who were found to be HTLV-1+ using ELISA (Diapro HTLV I-II Ab Kit, Milano, Italy) and a western blotting confirmatory test (MP kit, Singapore, Singapore) ). In addition, for control samples, a total of 118 blood donor specimens negative for HTLV-1 using ELISA(Diapro HTLV I-II Ab Kit, Milano, Italy) were selected. All participants were negative for Hepatitis B virus (HBV)), Hepatitis $\mathrm{C}$ virus (HCV), and Human immunodeficiency virus (HIV) tests. This study received ethics approval, with the number IR.IAU. PS.REC.1397.358 provided by the Ethics Committee of Islamic Azad University of Medical Sciences. Tehran, Iran. Also, all participants signed informed consent for entrance in the study.

\section{Genomic DNA extraction}

We used blood genomic DNA extraction mini kits (FavorGen, Ping-Tung, Taiwan) for isolation of genomic DNA from the buffy- coats of all samples PingTnng-, based on the manufacturer's instructions. Concentrations of genomic DNA were measured using a Nanodrop instrument (Denovix, Wilmington,).

\section{Identification of SNPs}

Two SNPs, namely rs3775291 and rs3775296, within the TLR3 gene were selected for this study ${ }^{17,18}$. Specific PCR primers were verified using the basic local alignment search tool (BLAST) at the NCBI site (https://www.ncbi.nlm.nih.gov/, Table 1). We prepared PCR amplification reagents in final volumes of $25 \mu \mathrm{L}$ (each reaction) consisting of $2 \times$ master mix (Ampliqon, Copenhagen, Denmark), $12.5 \mu \mathrm{L}$; forward primer $(10 \mu \mathrm{M}), 1 \mu \mathrm{L}$; primer reverse $(10 \mu \mathrm{M})$, $1 \mu \mathrm{L}$; template (1-100 ng), $2.5 \mu \mathrm{L}$; and $\mathrm{ddH}_{2} \mathrm{O}, 8 \mu \mathrm{L}$. PCR amplification was performed using specific primers, and the temperature profile included an initial denaturation step at $95^{\circ} \mathrm{C}$ for $5 \mathrm{~min}, 35$ cycles of $95^{\circ} \mathrm{C}$ for $45 \mathrm{~s}, 56^{\circ} \mathrm{C}$ for $45 \mathrm{~s}, 72^{\circ} \mathrm{C}$ for $45 \mathrm{~s}$, and finally an extension step at $72^{\circ} \mathrm{C}$ for $10 \mathrm{~min}$. Electrophoresis of PCR products was performed using 1.5\% agarose gels, and DNA Safe stain (FavorGen -) was used. Next, the bands were verified by gel documentation (ATP, Tehran,Iran). After viewing the specific bands for all samples, overnight enzymatic digestion (Table 1) was performed on the PCR products. The products of enzymatic digestion were verified using $2.5 \%$ agarose gels and DNA Safe dye (FavorGenPingTnng-) at 100 volts, and bands were revealed by gel imaging (ATPTehran-). Through these means, restriction fragmentation length polymorphism (RFLP) genotyping was performed on all PCR products (Table 1). DNA sequencing was used to establish reference standards for analyzing genotypes using PCR-RFLP.

\section{Statistical analysis}

For statistical analysis, SPSS software v.22.0 (SPSS, Inc., Chicago, IL, USA) was used. Hardy-Weinberg equilibrium (HWE) testing was individually used for all SNPs using Pearson's $\chi^{2}$ test. The $\chi^{2}$ test was used to compare the distribution of genotypes and

TABLE 1: Specifications of the study SNPs.

\begin{tabular}{|c|c|c|c|c|c|c|c|}
\hline Gene & SNP & Method & $\begin{array}{c}\text { Primer sequence } \\
\qquad\left(5^{\prime}-3^{\prime}\right)\end{array}$ & $\begin{array}{l}\text { Restriction } \\
\text { enzyme }\end{array}$ & Genotype & $\begin{array}{l}\text { Fragments size } \\
\text { (bp) }\end{array}$ & Reference \\
\hline \multirow[t]{8}{*}{ TLR3 } & rs3775291 & RFLP & $\begin{array}{l}\text { GGCTAAAAT- } \\
\text { GTTTGGAGCAC }\end{array}$ & HpyF3I* & TT & 200 & 17 \\
\hline & & & TGAGATTTTAT- & & & & \\
\hline & & & TCTTGGTTAG- & & $\mathrm{CT}$ & $31,169,200$ & \\
\hline & & & GCTGA & & & & \\
\hline & & & & & $\mathrm{CC}$ & 31,169 & \\
\hline & rs3775296 & RFLP & $\begin{array}{l}\text { GCATTTGAAA- } \\
\text { GCCATCTGCT }\end{array}$ & Mboll* & AA & 257,17 & 18 \\
\hline & & & $\begin{array}{l}\text { AAGTTGGCG- } \\
\text { GCTGGTAATCT }\end{array}$ & & $\mathrm{CA}$ & $279,257,17$ & \\
\hline & & & & & $\mathrm{CC}$ & 279 & \\
\hline
\end{tabular}

*(Thermo Scientific, Lithuania). 
frequencies of alleles between two groups. The level of statistical significance was set at 5\%. Logistic regression analysis was applied to compute $95 \%$ confidence intervals $(95 \% \mathrm{CI})$ and odds ratios (OR).

\section{RESULTS}

Our study population included 75 men $(75 \%)$ and 25 women $(25 \%)$ in the case group, and 104 men $(88.14 \%)$ and 14 women $(11.86 \%)$ in the control group. The average ages of patients and controls were $38.55 \pm 9.85$ and $36.72 \pm 9.93$ years, respectively. Frequencies of the TLR3 rs3775296 CC (wild type), CA (heterozygous), and AA (polymorphic homozygous) genotypes were $70 \%, 24 \%$, and $6 \%$ in HTLV-1 patients, and 50.8\%, 44.9\%, and $4.2 \%$ in the control group, respectively. Moreover, frequency of the TLR3 rs 3775296 C allele was $82 \%$ and $73.3 \%$ in the HTLV-1 patient and control groups, respectively. There was a significant difference in the distribution of TLR3 rs3775296 genotypes and frequencies of alleles between the patient and control groups $(p=0.002)$. A protective role of the genotypes CA with OR 0.388 and a $95 \%$ CI, of 0.215 to 0.702 and CA + AA with OR 0.443 and $(95 \% \mathrm{CI}, 0.253-0.776)]$, was observed against the disease
(Table 2 and Table 3). In addition, frequencies of the TLR3 rs3775291 CC (wild type), CT (heterozygous), and TT (polymorphic homozygous) genotypes were $52 \%, 43 \%$, and $5 \%$ in the HTLV-1 patient group, and $46.6 \%, 47.5 \%$, and $5.9 \%$ in the control group, respectively. The frequency of the TLR 3 rs $3775291 \mathrm{C}$ allele was also observed to be $70 \%$ in the HTLV-1 patient group and $70.3 \%$ in the control group. However, a statistically significant difference in the distribution of TLR3 rs3775291 genotypes, as well as in allele frequencies between the patient and control groups was not detected $(p=0.4)$ (Table 2 and Table 3 ). In addition, the genotype distributions did not significantly deviate from Hardy-Weinberg expectations for both groups ( $\mathrm{p}>0.05)(\mathrm{rs} 3775296,0.92$; rs3775291, 0.07).

\section{DISCUSSION}

Genetic alterations involving the TLR signaling pathway can cause susceptibility or resistance to several infectious diseases ${ }^{19-21}$. Given that TLR3 is capable of sensing dsRNA and stimulating the production of type I IFNs and inflammatory cytokines, it is clear that the receptor plays an important role in antiviral defense. In human, TLR3-promoter region has an important role in maintaining the integrity of the promoter and the specific responsive elements of the

TABLE 2: Distribution of TLR3 SNP genotypes in HTLV-infected cases and healthy controls.

\begin{tabular}{|c|c|c|c|c|c|c|}
\hline \multirow[t]{2}{*}{ SNP } & \multirow[t]{2}{*}{ Model } & \multirow[t]{2}{*}{ Genotype } & \multicolumn{2}{|c|}{ Genotype frequencies; n (\%) } & \multirow[t]{2}{*}{$p^{a}$} & \multirow[t]{2}{*}{ OR $(95 \% \mathrm{Cl})$} \\
\hline & & & HTLV-infected (100 cases) & Healthy (118 controls) & & \\
\hline \multirow[t]{7}{*}{ rs3775296 } & Codominan & $\mathrm{CC}$ & $70(70.0 \%)$ & $60(50.8 \%)$ & _ & ref \\
\hline & $t$ & $\mathrm{CA}$ & $24(24.0 \%)$ & $53(44.9 \%)$ & 0.002 & $0.388(0.215-0.702)$ \\
\hline & & $\mathrm{AA}$ & $6(6.0 \%)$ & $5(4.2 \%)$ & 0.964 & $1.029(0.299-3.540)$ \\
\hline & Dominant & $\mathrm{CC}$ & $70(70.0 \%)$ & $60(50.8 \%)$ & - & ref \\
\hline & & $C A+A A$ & $30(30.0 \%)$ & $58(49.2 \%)$ & 0.004 & $0.443(0.253-0.776)$ \\
\hline & Recessive & $\mathrm{CC}+\mathrm{CA}$ & $94(94 \%)$ & $113(95.8 \%)$ & - & ref \\
\hline & & AA & $6(6.0 \%)$ & $5(4.2 \%)$ & 0.554 & $1.443(0.427-4.876)$ \\
\hline \multirow[t]{7}{*}{ rs3775291 } & Codominant & $\mathrm{CC}$ & $52(52.0 \%)$ & $55(46.6 \%)$ & - & ref \\
\hline & & $\mathrm{CT}$ & $43(43.0 \%)$ & $56(47.5 \%)$ & 0.458 & $0.812(0.469-1.407)$ \\
\hline & & $\mathrm{TT}$ & $5(5.0 \%)$ & $7(5.9 \%)$ & 0.649 & $0.755(0.226-2.530)$ \\
\hline & Dominant & $\mathrm{CC}$ & $52(52.0 \%)$ & $55(46.6 \%)$ & - & ref \\
\hline & & $\mathrm{CT}+\mathrm{TT}$ & $48(48.0 \%)$ & $63(53.4 \%)$ & 0.428 & $0.806(0.473-1.374)$ \\
\hline & Recessive & $\mathrm{CC}+\mathrm{CT}$ & $95(95 \%)$ & $111(94.1 \%)$ & - & ref \\
\hline & & TT & $5(5.0 \%)$ & $7(5.9 \%)$ & 0.764 & $0.835(0.256-2.716)$ \\
\hline
\end{tabular}

a: $\mathrm{P}$ values were calculated using $\mathrm{X}^{2}$ test; SNP: single nuclear polymorphism, OR: odds ratio, Cl: confidence interval. 
TABLE 3: Allele distribution of TLR3 SNPs in HTLV-infected cases and healthy controls.

\begin{tabular}{|c|c|c|c|c|c|}
\hline \multirow{2}{*}{ SNP } & \multirow{2}{*}{ Allele } & \multicolumn{2}{|c|}{ Allele frequencies; $n$ (\%) } & \multirow{2}{*}{$\mathbf{P}^{\mathbf{a}}$} & \multirow{2}{*}{ OR $(95 \% \mathrm{Cl})$} \\
\hline & & HTLV-infected (100 cases) & Healthy (118 controls) & & \\
\hline \multirow{2}{*}{ rs377529 } & C & $164(82.0 \%)$ & $173(73.3 \%)$ & _- & ref \\
\hline & $A$ & $36(18.0 \%)$ & $63(26.7 \%)$ & 0.031 & $0.603(0.380-0.957)$ \\
\hline \multirow{2}{*}{ rs377529 } & C & $147(70.0 \%)$ & $166(70.3 \%)$ & - & ref \\
\hline & $\mathrm{T}$ & $63(30.0 \%)$ & $70(29.7 \%)$ & 0.938 & $1.016(0.677-1.526)$ \\
\hline
\end{tabular}

a: $\mathrm{P}$ values were calculated using $\mathrm{X}^{2}$ test; SNP: single nuclear polymorphism, OR: odds ratio, $\mathrm{Cl}$ : confidence interval.

promoter to viral agents. Malignant mutations and changes involving leucine to phenylalanine substitution at TLR3 amino acid location 412 (Leu412Phe) are among the effects of the rs3775291 polymorphism in TLR3 exon $4^{22}$. According to previous studies, this SNP does not affect the expression of TLR3, or its intracellular localization in vesicles, whereas it has negative effects on dsRNA binding ability and on cell surface expression of TLR $3^{23,24}$. Moreover, it has been suggested that promoter polymorphisms, such as TLR3 rs3775296, can influence gene expression in response to inflammatory cytokines and cause transcriptional modulation of TLR3.

In the current study, no significant association was observed involving TLR3 rs3775291 and susceptibility to HTLV-1 infection. However, there were significant differences in the distribution of TLR3 rs3775296 genotypes and allele frequencies between the patient and control groups. It seems that these observations may indicate a protective factor to prevent HTLV-1 infection. The protective genotypes included CA [OR (95\% CI)], 0.388 (0.215-0.702), and CA + AA [OR (95\% CI)], 0.443 (0.253-0.776), against HTLV-1 infection. There have been no studies concerning the association of SNPs within TLR3 (rs3775296 and rs3775291) with HTLV-1 infection in the Iranian population. To date, there are only reports regarding the association of SNPs within TLR3 and other viruses such as HIV and HCV. In a study by Sironi et al. (2012), TLR3 rs3775291 was genotyped in a group of Spanish HIV-seronegative individuals, despite their repeated exposure to HIV by i.v. injection drug use (IDU), whereas they had evidence of HCV-seropositivity. Significantly, the frequency of one homozygous rs3775291 allele in HIV-seronegative individuals was higher in comparison to controls. This research showed that a common TLR3 allele confers an immunological advantage that can protect against HIV-1 infection and proposed the potential use of stimulation of TLR3 levels in HIV-1 immunotherapy ${ }^{25}$. Enhanced sensitivity of TLR3 to stimulation may be due to increased expression of TLR3 in cells harboring the rs3775291 allele. Additionally, there are multiple reports that have highlighted the link between expression of TLR and response to HIV infection ${ }^{26}$, as well as in other physiological or pathological conditions ${ }^{27-29}$. In a study by Fischer et al. (2018), the importance of the TLR3 rs3775291 polymorphism was shown in the natural course of chronic HBV infection among patients. The polymorphic TLR3 rs3775291 A allele is associated with decreased possibility of spontaneous clearance of Hepatitis B surface antigen (HBsAg) and Hepatitis B e-antigen (HBeAg) in serum, and an increased risk of developing chronic hepatitis B. Haplotype analysis revealed that the variant $\mathrm{rs} 3775291 \mathrm{~A}$ presents the lowest possibility of clearance of HBsAg in serum ${ }^{30}$. In a study by Guedes de Sá et al. (2015), the prevalence of two SNPs (rs3775291) in the TLR3 gene was investigated in patients infected with $\mathrm{HBV}, \mathrm{HCV}$, and healthy controls. However, there were no significant differences in the frequencies of alleles, genotypes and haplotypes between the studied groups ${ }^{16}$. Zayed et al. (2017) in their study investigated possible associations involving genetic variations in TLR3 with $\mathrm{HCV}$ infection, and hepatic fibrosis in patients with chronic HCV in Egypt. Genotyping of TLR3 rs3775296 was carried out on naïve chronic HCV-positive patients and on healthy controls using the PCR-RFLP technique. They reported that the frequency of polymorphic genotypes involving TLR3 rs3775296 was not significantly different between $\mathrm{HCV}$-positive patients and controls ${ }^{18}$. In a study by Motavaf et al. (2014), it was reported that patients with chronic HCV infection have lower levels of TLR3 and TLR7 expression ${ }^{31}$.

Studzinska et al. (2016) investigated the association between TLR3 rs3775291 and rs3775296 SNPs and viral infection in Cytomegalovirus (CMV)-positive children(Cytomegalovirus). They reported an increase in the frequency of heterozygous TLR3 rs3775291 genotypes in children with HCMV infection in comparison to uninfected controls. Being heterozygous at the rs3775291 SNP was related to increased risk of HCMV disease. In addition, individuals heterozygous at rs3775296 exhibited an increased relative risk of CMV infection, although this association was not statistically significant for multiple experiments after correction.

Those authors suggested that polymorphism involving rs3775291 in TLR3 could be a genetic risk factor for the development of CMV ${ }^{32}$. 
Our results also revealed no significant association between the TLR3 rs3775291 SNP and HTLV-1 infection. However, TLR3 rs3775296 SNP was significantly associated with such infection and appears to be a protective factor against HTLV-1 infection. Finally, the possible influence of polymorphisms in terms of infection control mechanisms should be considered ${ }^{18,20}$.

\section{ACKNOWLEDGMENTS}

We gratefully acknowledge the staff at the virology lab of the Blood Transfusion Research Center, and the High Institute for Research and Education in Transfusion Medicine, for their advice and technical support.

\section{FINANCIAL SUPPORT}

This study was carried out with the financial support of the High Institute for Research and Education in Transfusion Medicine, and the Blood Transfusion Research Center.

\section{AUTHORS' CONTRIBUTIONS}

HMH: Conception and design of the study, Acquisition of data, analysis and interpretation of data, drafting of the manuscript. MP: Conception and design of the study, analysis and interpretation of data, critical revision of the manuscript for important intellectual content. AAP: Conception and design of the study, analysis and interpretation of data. SH: Conception and design of the study. ZS: Conception and design of the study, analysis and interpretation of data, statistical analysis, critical revision of the manuscript for important intellectual content, final approval of the version to be submitted.

\section{CONFLICT OF INTEREST}

We declare that we have no conflicts of interest.

\section{REFERENCES}

1. Matsuoka M, Jeang KT. Human T-cell leukemia virus type I at age 25: a progress report. Cancer Res. 2005;65(11):4467-70.

2. Proietti FA, Carneiro-Proietti AB, Catalan-Soares BC, Murphy EL. Global epidemiology of HTLV-I infection and associated diseases. Oncogene. 2005;24(39):6058-68.

3. Vrielink H, Reesink HW. HTLV-I/II prevalence in different geographic locations. Transfus Med Rev. 2004;18(1):46-57.

4. Takao S, Ishida T, Bhatia KK, Saha N, Soemantri A, Kayame OW. Seroprevalence of human T-lymphotropic virus type 1 in Papua New Guinea and Irian Jaya measured using different western blot criteria. J Clin Virol. 2000;16(2):129-33.

5. Sanclemente G, Moreno A, Navasa M, Lozano F, Cervera C. Genetic variants of innate immune receptors and infections after liver transplantation. World J Gastroenterol. 2014;20(32):11116-30.

6. Skevaki C, Pararas M, Kostelidou K, Tsakris A, Routsias JG. Single nucleotide polymorphisms of Toll-like receptors and susceptibility to infectious diseases. Clin Exp Immunol. 2015;180(2):165-77.

7. Medzhitov R, Janeway C Jr. Innate immune recognition: mechanisms and pathways. Immunol Rev. 2000;173:89-97.

8. Medhi S, Deka M, Deka P, Swargiary SS, Hazam RK, Sharma MP, et al. Promoter region polymorphism \& expression profile of toll like receptor-3 (TLR3) gene in chronic hepatitis $\mathrm{C}$ virus (HCV) patients from India. Indian J Med Res. 2011;134:200-7.
9. Liu F, Lu W, Qian Q, Qi W, Hu J, Feng B. Frequency of TLR 2, 4, and 9 gene polymorphisms in Chinese population and their susceptibility to type 2 diabetes and coronary artery disease. J Biomed Biotechnol. 2012;2012:373945.

10. Yang HY, Lee HS, Lee CH, Fang WH, Chen HC, Salter DM, et al. Association of a functional polymorphism in the promoter region of TLR-3 with osteoarthritis: a two-stage case-control study. J Orthop Res. 2013;31(5):680-5.

11. Fan L, Zhou P, Hong Q, Chen AX, Liu GY, Yu KD, et al. Toll-like receptor 3 acts as a suppressor gene in breast cancer initiation and progression: a two-stage association study and functional investigation. Oncoimmunology. 2019;8(6):e1593801.

12. Al-Qahtani A, Al-Ahdal M, Abdo A, Sanai F, Al-Anazi M, Khalaf N, et al. Toll-like receptor 3 polymorphism and its association with hepatitis B virus infection in Saudi Arabian patients. J Med Virol. 2012;84(9):13539.

13. He D, Tao S, Guo S, Li M, Wu J, Huang H, et al. Interaction of TLR-IFN and HLA polymorphisms on susceptibility of chronic HBV infection in Southwest Han Chinese. Liver Int. 2015;35(8):1941-1949.

14. Li G, Zheng Z. Toll-like receptor 3 genetic variants and susceptibility to hepatocellular carcinoma and HBV-related hepatocellular carcinoma. Tumour Biol. 2013;34(3):1589-94.

15. Qian F, Bolen CR, Jing C, Wang X, Zheng W, Zhao H, et al. Impaired Toll-Like Receptor 3-Mediated Immune Responses from Macrophages of Patients Chronically Infected with Hepatitis C Virus. Clin Vaccine Immunol. 2013;20(2):146-55.

16. Sá KS, Pires-Neto Ode S, Santana BB, Gomes ST, Amoras Eda S, Conde $\mathrm{SR}$, et al. Toll-like receptor 3 gene polymorphisms are not associated with the risk of hepatitis B and hepatitis C virus infection. Rev Soc Bras Med Trop. 2015;48(2):136-42.

17. Noguchi E, Nishimura F, Fukai H, Kim J, Ichikawa K, Shibasaki M, et al. An association study of asthma and total serum immunoglobin $\mathrm{E}$ levels for Toll-like receptor polymorphisms in a Japanese population. Clin Exp Allergy. 2004;34(2):177-83.

18. Zayed RA, Omran D, Mokhtar DA, Zakaria Z, Ezzat S, Soliman MA, et al. Association of Toll-Like Receptor 3 and Toll-Like Receptor 9 Single Nucleotide Polymorphisms with Hepatitis C Virus Infection and Hepatic Fibrosis in Egyptian Patients. Am J Trop Med Hyg. 2017;96(3): $720-6$.

19. Cheng PL, Eng HL, Chou MH, You HL, Lin TM. Genetic polymorphisms of viral infection-associated Toll-like receptors in Chinese population. Transl Res. 2007;150(5):311-8.

20. Schröder NW, Schumann RR. Single nucleotide polymorphisms of Tolllike receptors and susceptibility to infectious disease. Lancet Infect Dis. 2005;5(3):156-64.

21. Turvey SE, Hawn TR. Towards subtlety: understanding the role of Toll-like receptor signaling in susceptibility to human infections. Clin Immunol. 2006;120(1):1-9.

22. Yang Z, Stratton C, Francis PJ, Kleinman ME, Tan PL, Gibbs D, et al. Toll-like receptor 3 and geographic atrophy in age-related macular degeneration. N Engl J Med. 2008;359(14):1456-63.

23. Ranjith-Kumar CT, Miller W, Sun J, Xiong J, Santos J, Yarbrough I, et al. Effects of single nucleotide polymorphisms on Toll-like receptor 3 activity and expression in cultured cells. J Biol Chem. 2007;282(24):17696-705.

24. Zhou P, Fan L, Yu KD, Zhao MW, Li XX. Toll-like receptor 3C1234T may protect against geographic atrophy through decreased dsRNA binding capacity. FASEB J. 2011;25(10):3489-95. 
25. Sironi M, Biasin M, Cagliani R, Forni D, De Luca M, Saulle I, et al. A Common Polymorphism in TLR3 Confers Natural Resistance to HIV-1 Infection. J Immunol. 2012;188(2):818-23.

26. Lester RT, Yao XD, Ball TB, McKinnon LR, Kaul R, Wachihi C, et al. Toll-like receptor expression and responsiveness are increased in viraemic HIV-1 infection. AIDS. 2008;22(6):685-694.

27. Jaekal J, Abraham E, Azam T, Netea MG, Dinarello CA, Lim JS, et al. Individual LPS responsiveness depends on the variation of toll-like receptor (TLR) expression level. J Microbiol Biotechnol. 2007;17(11):1862-7.

28. Petit-Bertron AF, Tabary O, Corvol H, Jacquot J, Cle'ment A, Cavaillon $\mathrm{JM}$, et al. Circulating and airway neutrophils in cystic fibrosis display different TLR expression and responsiveness to interleukin-10. Cytokine. 2008;41(1):54-60.
29. Schoneveld AH, Hoefer I, Sluijter JP, Laman JD, de Kleijn DP, Pasterkamp G. Atherosclerotic lesion development and Toll like receptor 2 and 4 responsiveness. Atherosclerosis. 2008;197(1):95-104.

30. Fischer J, Koukoulioti E, Schott E, Fülöp B, Heyne R, Berg T, et al. Polymorphisms in the Tolllike receptor 3 (TLR3) gene are associated with the natural course of hepatitis B virus infection in Caucasian population. Sci Rep. 2018;8:12737.

31. Motavaf M, Noorbakhsh F, Alavian SM, Sharifi Z. Distinct Tolllike Receptor 3 and 7 Expression in Peripheral Blood Mononuclear Cells From Patients with Chronic Hepatitis C Infection. Hepat Mon. 2014;14(4):e16421.

32. Studzińska M, Jabłońska A, Wiśniewska Ligier M, Nowakowska D, Gaj Z, Leśnikowski ZJ, et al. Association of TLR3 L412F Polymorphism with Cytomegalovirus Infection in Children. PLoS ONE. 2017;12(1):e0169420. 